Original Article

\title{
Comparison of the effects of hamstring stretching using proprioceptive neuromuscular facilitation with prior application of cryotherapy or ultrasound therapy
}

\author{
Francisco Elezier Xavier Magalhães ${ }^{1,2)}$, Arlindo Rodrigues de Mesquita Junior ${ }^{1)}$, \\ Harnold’s Tyson de Sousa Meneses ${ }^{1)}$, Rayele Pricila Moreira dos Santos ${ }^{1,3,4)}$, \\ Ezaine Costa Rodrigues ${ }^{1,4)}$, Samara Sousa Vasconcelos Gouveia ${ }^{5}$, \\ Guilherme Pertinni de Morais Gouveia ${ }^{5)}$, Marco Orsini ${ }^{6,7)}$, \\ Victor Hugo do Vale Bastos ${ }^{4,8)^{*}}$, Dionis de Castro Dutra Machado ${ }^{4,8}$ \\ 1) Federal University of Piaui (UFPI), Brazil \\ 2) Biotecnology Master Program (UFPI), Brazil \\ 3) Biomedical Sciences Master Program (UFPI), Brazil \\ 4) Brain Mapping and Functionality Laboratory (LAMCEF/UFPI), Brazil \\ 5) Research Group in Physical Therapy Evaluative and Therapeutic-GPFAT, Research Laboratory of \\ Physical Therapy Evaluative and Therapeutic - LaFAT, Brazil \\ 6) Department of Neurology, Federal Fluminense University (UFF), Brazil \\ 7) Rehabilitation Science Master Program, Augusto Motta University Center (UNISUAM), Brazil \\ 8) Brain Mapping and Sensory Motor Integration, Institute of Psychiatry of Federal University of Rio \\ de Janeiro (IPUB/UFRJ), Brazil
}

\begin{abstract}
Purpose] Stretching using proprioceptive neuromuscular facilitation involve physiological reflex mechanisms through submaximal contraction of agonists which activate Golgi organ, promoting the relaxation reflex. The aim of this study was to evaluate the effects of proprioceptive neuromuscular facilitation alone and with prior application of cryotherapy and thermotherapy on hamstring stretching. [Subjects and Methods] The sample comprised of 32 young subjects with hamstring retraction of the right limb. The subjects were randomly allocated to four groups: the control, flexibility PNF, flexibility PNF associated with cryotherapy, flexibility PNF in association with ultrasound therapy. [Results] After 12 stretching sessions, experimental groups showed significant improvements compared to the control group. Moreover, we did not find any significant differences among the experimental groups indicating PNF stretching alone elicits similar results to PNF stretching with prior administration of cryotherapy or thermotherapy. [Conclusion] PNF without other therapy may be a more practical and less expensive choice for clinical care.

Key words: Proprioceptive neuromuscular facilitation, Thermotherapy, Cryotherapy
\end{abstract}

(This article was submitted Nov. 19, 2014, and was accepted Jan. 31, 2015)

\section{INTRODUCTION}

Flexibility is free movement, without impediment and within the physiological limit of each joint. Reduced flexibility results in muscular retraction ${ }^{1,2)}$ which limits range of motion (ROM), and is frequently caused by a periarticular soft tissue adaptation. Other factors that may cause muscular retraction include prolonged immobility and limited mobility caused by various diseases that affect the skeletal,

\footnotetext{
*Corresponding author. Victor Hugo do Vale Bastos (E-mail: victorhugobastos@ufpi.edu.br)

(C2015 The Society of Physical Therapy Science. Published by IPEC Inc. This is an open-access article distributed under the terms of the Creative Commons Attribution Non-Commercial No Derivatives (by-ncnd) License $<$ http://creativecommons.org/licenses/by-nc-nd/3.0/>.
}

nervous, muscular and articular systems. Regardless of cause, muscular retraction will cause functional limitations in performance of various daily activites ${ }^{1-4)}$.

Exercises for increasing flexibility are used in physical therapy for the treatment of muscular retraction and to prevent greater functional losses ${ }^{5}$. These exercises provide various benefits through pain relief and reduce the risk of injuries. Among them, the most used are ballistic/dynamic and static stretching and through proprioceptive neuromuscular facilitation $(\mathrm{PNF})^{6-8)}$. Several reflex physiological mechanisms, such as reflex relaxation, which is promoted by activating the Golgi organ during contractions of the agonist, are involved in PNF stretching. The contract-relax technique is a PNF modality which requires the submaximal isometric contraction of the muscle after it has been for being stretched for a certain length of time. Afterwards, the segment is passively moved to the limit point of the subject's 
stretching sensation the point at which some discomfort $\left.{ }^{9}, 10\right)$ is reported. When applied correctly, this technique provokes reflex relaxation, facilitating passive stretching and improving $\mathrm{ROM}^{11)}$.

Flexibility training is often used in clinical and sporting practice and the demand for physical resources for potentializing their effects has become increasingly frequent. Various studies have examined the efficacy of thermotherapy modalities for the enhancement of flexibility exercises ${ }^{11-14)}$. Cryotherapy decreases nervous conduction velocity and consequently, pain and muscle spindle discharge. It is a modality widely used in clinical practice. Applying ice prior to stretching optimizes improvements in flexibility, since the muscle reflex response and pain are considered the main barriers to stretching maneuvers ${ }^{11,12)}$. Due to subject's increasing tolerance to stretching maneuvers, the prior use of cryotherapy requires attention in the act of stretching so as not to exceed a patient's physiological limits ${ }^{15}$. Thermotherapy is another modality that has been extensively investigated as a factor enhancing the results of the stretching, since it effectively changes conjunctive tissues viscoelastic properties $^{16-18)}$.

Various studies have attempted to establish the effects of thermotherapy combined with stretching, but most of them have sought to elucidate the effects of thermotherapeutic modalities associated with static stretching ${ }^{13,14)}$ and few have evaluated their association with PNF stretching. Accordingly, the aim study was to evaluate the effects on hamstring flexibility of PNF stretching using the variant contract-relax with prior application of cryotherapy or thermotherapy.

\section{SUBJECTS AND METHODS}

This study was conducted at the School Clinic of the Federal University of Piauí and included healthy subjects who were recruited through notices placed on bulletin boards. The sample comprised 32 volunteers (men and women), aged 20 to 25 years old (mean 22.4), all healthy (according previous anamnesis), right-handed, and sedentary, who had body mass indexes within the normal rang, and showed knee extension less than or equal to $155^{\circ}$. Subjects with muscle injury of the lower limbs, fractures, inflammatory or infectious diseases, or hypersensitivity to ice or heat application were excluded. All the volunteers were informed about the procedures and signed an informed consent form. This study was a randomized and prospective clinical trial, which was approved by the Research Ethics Committee of the State University of Piaui - UESPI with $n^{\circ} 188.420$.

The subjects were instructed to not practice physical exercises during the intervention period, so as not to influence the results. Twelve experimental sessions, three each week, were performed and the results of the popliteal angle range of extension, measured by goniometry and Wells' bench test evaluated before and after the first and last sessions were compared. During right knee popliteal angle measurement, the subjects lay supine on a gurney and the examined leg was positioned to produce hip flexion of $90^{\circ}$, with the contralateral leg resting on a wedge of foam that kept hip flexion and the knee at $90^{\circ}$ to stabilize the lumbo pelvic region. Then, the examiner requested the subject to perform an active knee extension. In order to measure the popliteal angle, a goniometer was positioned on the lateral condyle, with the fixed arm oriented to the greater trochanter and the movable arm parallel to the leg.

The measures were performed three consecutive times and the arithmetic mean was calculated. After active knee extension angle evaluation, the subjects were instructed to sit facing the Wells' bench, placing their feet flat on the box bench base with their knees extended. They then raised their upper limbs with overlapping hands, moving both forward through trunk flexion, to reach the greatest possible distance on the ruler without bending their knees and without performing additional movements. So as to minimize execution errors the evaluator remained beside the subjects, to ensure their knees were extended. The movement was performed three times, and the best result, the furthest distance that a subject could reach on the scale with tips of the fingers was recorded ${ }^{13,19,20)}$.

The subjects were randomly allocated four groups of 8 subjects each: the control, PNF flexibility (PNF), PNF flexibility with cryotherapy (PNFCRYO), and PNF flexibility with ultrasound thermotherapy (PNFUS) groups. The control group received an initial and final evaluation but did not receive any type of intervention. The PNF group was subjected to hamstring stretching PNF through the contact-relax technique. They performed a submaximal isometric muscle contraction for about five seconds, followed by relaxation. Then, this segment was passively moved to the pain-limiting point of each subject's stretching range and maintained in this position for 30 seconds. In each experimental session, a series of four repetitions of this type of stretching was performed with 10 -second intervals between them. This protocol was performed three times a week, for four weeks ${ }^{12,21)}$.

The PNFCRYO group was subjected to the same protocol as the PNF flexibility group, but with the prior application of cryotherapy. Ice packages with a temperature $0^{\circ}$ to $5^{\circ}$ degrees were wrapped in a damp cloth and placed for during 20 minutes on the belly of the hamstring. The PNFUS group performed PNF stretching immediately after receiving ultrasound heat treatment for the muscle belly, at a frequency of $1 \mathrm{MHz}$ in continuous mode with an intensity of $1 \mathrm{~W} / \mathrm{cm}^{2}$ for five minutes. Water-based gel was used as the coupling for the ultrasound head with the treatment area, as well as for the propagation of sound waves. The ultrasound had an effective radiation area of $5 \mathrm{~cm}^{2}$ and was moved in a circular pattern at about $4 \mathrm{~cm} / \mathrm{s}$ to prevent the formation of standing waves which are responsible for excessive local heating.

The data were analyzed using the statistical package SPSS 19.0. In all analyses, values of $\mathrm{p} \leq 0.05$ were considered significant. The homogeneity of the sample was tested using the Kolmogorov-Smirnov test. The results of the Wells' bench test and goniometry were evaluated and compared using one-way ANOVA and Tukey's HSD post hoc test.

\section{RESULTS}

This study included 32 subjects, 14 males (43.8\%) and 18 females $(56.2 \%)$, who were divided equally into four groups: Control, PNF, PNFCRYO, and PNFUS. Table 1 shows their age data, and Wells' bench test and goniometry 
Table 1. Sample descriptive characteristics according to age, wells' bench and goniometry measures before (initial evaluation) and after (final evaluation) intervention procedures

\begin{tabular}{lccc}
\hline & Minimum & Maximum & Mean \\
\hline Age & 20 & 25 & 22.4 \\
Wells & & & \\
Initial & $30 \mathrm{~cm}$ & $71 \mathrm{~cm}$ & $53 \mathrm{~cm}$ \\
Final & $32 \mathrm{~cm}$ & $69 \mathrm{~cm}$ & $57.7 \mathrm{~cm}$ \\
Goniometry & & & \\
Initial & $122^{\circ}$ & $158^{\circ}$ & $140.7^{\circ}$ \\
Final & $125^{\circ}$ & $172^{\circ}$ & $155.3^{\circ}$ \\
\hline
\end{tabular}

Table 2. Comparison initial and final means for Wells' bench (Unit: $\mathrm{cm}$ )

\begin{tabular}{lc}
\hline Wells' bench & Mean \pm SD \\
\hline Initial control & $48.63 \pm 3.67$ \\
Final control & $48.63 \pm 3.38$ \\
Initial PNF & $53.63 \pm 3.26$ \\
Final PNF & $61.50 \pm 1.62$ \\
Initial PNFUS & $54.63 \pm 3.32$ \\
Final PNFUS & $59.75 \pm 2.25$ \\
Initial PNFCRYO & $55.13 \pm 2.54$ \\
Final PNFCRYO & $61.25 \pm 1.03$ \\
\hline
\end{tabular}

Table 3. Initial and final mean of movement amplitude measured through goniometry (Unit: $\mathrm{cm}$ )

\begin{tabular}{lc}
\hline Goniometry & Mean \pm SD \\
\hline Initial control & $135.16 \pm 2.89$ \\
Final control & $140.62 \pm 5.28$ \\
Initial PNF & $135.16 \pm 3.08$ \\
Final PNF & $160.41 \pm 1.91$ \\
Initial PNFUS & $146.74 \pm 2.20$ \\
Final PNFUS & $160.53 \pm 2.62$ \\
Initial PNFCRYO & $145.74 \pm 3.16$ \\
Final PNFCRYO & $159.82 \pm 2.62$ \\
\hline
\end{tabular}

knee extension results.

The results presented in Table 2 show the evaluations of the Wells' bench of the Control, PNF, PNFUS and PNFCRYO groups. The Kolmogorov-Smirnov test indicated the initial and final values of each of the groups had gaussian data distribution. One-way ANOVA was used to compare the initial results of the Wells' bench test. No significant differences were found. One-way ANOVA indicated there were significant differences among the groups' final values $(\mathrm{p}=0.001)$. Tukey's HSD post hoc found no significant differences between groups, but the final values of the experimental groups significantly differed from the control group: being Control vs. PNF, $\mathrm{p}=0.002$; Control vs. PNFUS, $\mathrm{p}=0.008$; and Control vs. PNFCRYO, $\mathrm{p}=0.002$.

Table 3 shows the results of goniometry of knee extension from the initial position of hip and knee flexion of $90^{\circ}$ in the supine position. One-way ANOVA was used to compare the initial and final angles $(\mathrm{p}=0.007)$ of all the groups, and the results indicate that were differences among the groups before the start of the intervention. After the intervention, this difference became even more significant $(p=0.000)$. Tukey's HSD post hoc test found there were significant differences between the experimental groups and the control group in the initial and final angles: Control vs. PNF, $\mathrm{p}=0.001$; Control vs. PNFUS, $\mathrm{p}=0.001$; and Control vs. PNFCRYO, $\mathrm{p}=0.002$ ).

\section{DISCUSSION}

This study aimed to evaluate the effects on flexibility of training using a contract-relax technique for the hamstrings and to compare it with prior application of cryotherapy or thermotherapy. Studies of exercises and methods that improve flexibility are common in the literature. Flexibility training methods (static stretching, dynamic and PNF) are used to improve range of motion, and heat or cold are sometimes used to enhance effect. After 12 treatment sessions the hamstrings stretching protocol, elicited flexibility gains in all groups and the results show that the prior use of cryotherapy or thermotherapy did not enhance the effect of the flexibility training.

To investigate the effects of stretching modalities on ROM, muscle activation and balance, a study employed static stretching, PNF stretching and no stretching for 48 adult males with hamstring muscle tightness who were randomly divided into three groups. The stretching modalities were performed once for the hamstring, and active knee extension angle, muscle activation during maximum voluntary isometric contraction (MVC), and static balance were measured before and after the application of each stretching modality. Both modalities were successful at increasing the knee extension angle compared to the control group, but there were no significant differences in MVC or static balance $^{22)}$. In the present study, ROM improved after hamstring stretching PNF using the contact-relax technique. Moreover, exercise programs using PNF techniques are known to be effective at improving the function of myofascial pain syndrome patients ${ }^{23)}$. In our sample, the subjects were healthy, and although they showed limited extension of the knee, they did not have pain. It is useful to note that PNF stretching could be effective at decreasing pain.

Comparing the static stretching alone and with cryotherapy, Busarello et al. ${ }^{24)}$, verified that cryotherapy minimizes discomfort during flexibility training enabling increase of the movement range. The 20 subjects analyzed were 18-25 years old and received ice packages on the hamstring for 15 minutes, followed by static stretching in two series of 30 seconds. Significant differences were found in hamstring extensibility in both groups; however, the use of cryotherapy did not effectively increase extensibility. In the present study, cryotherapy elicited results similar to the group that did not use cryotherapy prior to flexibility training ${ }^{12,14)}$.

The results of the present study corroborate the findings of Mallmann et al. ${ }^{25}$, who demonstrated a significant gain 
in hamstring flexibility in a PNF group. They evaluated and compared the immediate and acute effects of three stretching protocols (static, passive stretching, and PNF) for the hamstring and paraspinal muscles, with stretching $32 \mathrm{~s}$. Wells' bench results indicated that there were significant differences in all experimental groups between the first and second evaluations. However, they found no significant difference when they compared the protocols, both in the Wells' bench test and the goniometry results. Similarly, the present study compared the pre- and post-intervention results of the PNF, PNFUS and PNFCRYO groups and found there were no significant differences among them.

Knight et al. ${ }^{26)}$ compared stretching using superficial heat, profound/deep heat, or active heating to increase the plantar flexors' extensibility in an intervention of six weeks. A hot water bag was used for superficial heating, continuous ultrasound with a frequency $1 \mathrm{MHz}$ for 7 minutes, for profound/ deep heat, and exercise to stay on the toes for active heating. Continuous ultrasound was the most effective modality for improving dorsiflexion ROM. This result contrasts with our present results, which show that there was no greater effect of flexibility training when it was combined with ultrasound thermotherapy. However, this study used only five minutes ultrasound therapy before PNF stretching, unlike the study of Knight et al. ${ }^{24)}$ which used 7 minutes.

In the study of Funk et al. ${ }^{27)}$, the subjects were divided into two groups. One performed only static stretching, and the other used only a hot water bag for 20 minutes. The group that used the hot water bag showed a flexibility gain that was greater than that of the static stretching group. This result differs from results of the present study, in which the group that performed PNF stretching technique with ultrasound therapy demonstrated results similar to the PNF group. Burke et al. ${ }^{11)}$ evaluated and compared increase in ROM of hip flexion after static stretching with prior heating or cooling. They reported that there was no statistical difference in movement range gain between the groups. These results are in agreement with our present results that show there was no significant improvement with the use of thermotherapy.

In one of his studies Draper et al. ${ }^{18)}$ evaluated flexibility gain hamstring in three different groups: control, short wave diathermy plus stretching, and short wave diathermy placebo plus stretching. They selected 30 students with inability to maintain movement amplitude of $160^{\circ}$ knee extension at $90^{\circ}$ of hip flexion and the goniometric measures made before and after each experimental session during five days. The diathermy plus stretching group received 10 minutes diathermy (distal hamstrings), followed by 5 minutes of simultaneous diathermy and stretching, and finally 5 min of only stretching. The placebo diathermy and stretching group followed the same protocol, but with the diathermy unit off. Draper et al. concluded that short wave diathermy with stretching improved hamstring flexibility, differing from the results of the present study, in which the results of the PNFUS group did not significantly differ from those of the group that performed only PNF. A possible explanation for this difference is that short wave diathermy affects a larger operational area than the ultrasound used in the present study.

Russo et al. ${ }^{28)}$ analyzed and compared active flexibility training versus active stretching with therapeutic ultrasound in 51 male volunteers, young adults and not physically active. Using goniometry they evaluated the flexibility before and after treatment and reported that in the intragroup comparison, all groups showed improved hamstring flexibility, but in the comparison of groups, only the active stretching group showed a significant ROM gain in knee extension. These results agree with those of both the intra- and intergroup comparisons of the present study. They show increased movement range; however, the studies differ, because our study there was no preponderance of one group over another, but an opportunity to choose the effective therapy considering time spent and benefits achieved.

The effects of therapeutic ultrasound on ROM and stretch pain and the relationships between the effects were analyzed in a study conducted with 15 healthy males. The subjects received three interventions: ultrasound (US group), sham ultrasound without power (placebo group), and rest (control group). Ultrasound was applied for 10 minutes at $3 \mathrm{MHz}$ with an intensity of $1.0 \mathrm{~W} / \mathrm{cm}^{2}$ and a $100 \%$ duty cycle on the upper fibers of the right trapezius muscle. The evaluation indices were active and passive ROM, stretch pain (visual analog scale; VAS), and skin surface temperature (SST). The results showed there were significant increases in ROM and SST after ultrasound, without any change in stretch pain ${ }^{29)}$. In our study, we opted to use ultrasound at $1 \mathrm{MHz}$ due to its depth of action and the localization of the target muscle.

Analyzing the data presented, we conclude that all experimental groups showed greater increases in flexibility and better ROM than the control group. Moreover, the use of the PNF technique alone elicited results similar to the other techniques of profound/deep heat provided by continuous ultrasound, and cryotherapy. Among the interventions investigated in this study, PNF stretching seems to be more appropriate for clinical practice since it depends only on the technical skill of the therapist, and does not require equipment for electro-thermotherapy, as well as being faster and less burdensome to execute.

\section{REFERENCES}

1) Williams GN, Higgins MJ, Lewek MD: Aging skeletal muscle: physiologic changes and the effects of training. Phys Ther, 2002, 82: 62-68. [Medline]

2) Polachini LO, Fusazaki L, Tamaso M, et al.: Estudo comparativo entre três métodos de avaliação do Encurtamento de musculatura posterior de coxa. Rev Bras Fisioter, 2005, 9: 187-193.

3) Bertolla F, Baroni MB, Junior LP, et al.: Efeito de um programa de treinamento utilizando o método Pilates na flexibilidade de atletas juvenis de futsal. Rev Bras Med Esporte, 2007, 13: 222-226. [CrossRef]

4) Carregaro RL, Silva LC, Gil HJ: Comparação entre dois testes clínicos para avaliar a flexibilidade dos músculos posteriores da coxa. Rev Bras Fisioter, 2007, 11: 139-145. [CrossRef]

5) O'Sullivan K, Murray E, Sainsbury D: The effect of warm-up, static stretching and dynamic stretching on hamstring flexibility in previously injured subjects. BMC Musculoskelet Disord, 2009, 10: 37. [Medline] [CrossRef]

6) Sweeting D, Parish B, Hooper L, et al.: The effectiveness of manual stretching in the treatment of plantar heel pain: a systematic review. J Foot Ankle Res, 2011, 4: 19. [Medline] [CrossRef]

7) Mahieu NN, Cools A, De Wilde B, et al.: Effect of proprioceptive neuromuscular facilitation stretching on the plantar flexor muscle-tendon tissue properties. Scand J Med Sci Sports, 2009, 19: 553-560. [Medline] [CrossRef]

8) Feland JB, Marin HN: Effect of submaximal contraction intensity in contract-relax proprioceptive neuromuscular facilitation stretching. Br J Sports Med, 2004, 38: E18. [Medline] [CrossRef] 
9) Mortari DM, Mânica AP, Pimentel GL: Efeitos da crioterapia e facilitação neuromuscular proprioceptiva sobre a força muscular nas musculaturas flexora e extensora de joelho. Fisioter Pesq, 2009, 16: 329-334. [CrossRef]

10) Westwater-Wood S, Adams N, Kerry R: The use of proprioceptive neuromuscular facilitation in physiotherapy practice. Phys Ther Rev, 2010, 15: 23-28. [CrossRef]

11) Burke DG, Holt LE, Rasmussen R, et al.: Effects of hot or cold water immersion and modified proprioceptive neuromuscular facilitation flexibility exercise on hamstring length. J Athl Train, 2001, 36: 16-19. [Medline]

12) Brasileiro JS, Faria AF, Queiroz LL: Influência do resfriamento e do aquecimento local na flexibilidade dos músculos isquiotibiais. Rev Bras Fisioter, 2007, 11: 57-61. [CrossRef]

13) Signori LU, Voloski FR, Kerkhoff AC, et al.: Efeito de agentes térmicos aplicados previamente a um programa de alongamentos na flexibilidade dos músculos isquiotibiais encurtados. Rev Bras Med Esporte, 2008, 14 : 328-331. [CrossRef]

14) Silva AS, Oliveira DJ, Jaques MJ, et al.: Efeito da crioterapia e termoterapia associados ao alongamento estático na flexibilidade dos músculos isquiotibiais. Motri, 2010, 6: 55-62.

15) Kanlayanaphotporn R, Janwantanakul P: Comparison of skin surface temperature during the application of various cryotherapy modalities. Arch Phys Med Rehabil, 2005, 86: 1411-1415. [Medline] [CrossRef]

16) Robertson VJ, Ward AR, Jung P: The effect of heat on tissue extensibility: a comparison of deep and superficial heating. Arch Phys Med Rehabil, 2005, 86: 819-825. [Medline] [CrossRef]

17) Baker KG, Robertson VJ, Duck FA: A review of therapeutic ultrasound: biophysical effects. Phys Ther, 2001, 81: 1351-1358. [Medline]

18) Draper DO, Miner L, Knight KL, et al.: The Carry-Over effects of diathermy and stretching in developing hamstring flexibility. J Athl Train, 2002, 37: 37-42. [Medline]

19) Chebel KJ, Galuppo DF, Sá CS, et al.: Estudo comparativo entre dois tipos de alongamento Muscular através do ganho de amplitude articular. RBCS, 2007, 6: 27-31

20) Norris CM, Matthews M: Inter-tester reliability of a self-monitored active knee extension test. J Bodyw Mov Ther, 2005, 9: 256-259. [CrossRef]

21) Gama ZA, Dantas AV, Souza TO: Influência do intervalo de tempo entre as sessões de alongamento no ganho de flexibilidade dos isquiotibiais. Rev Bras Med Esporte, 2009, 15: 110-114. [CrossRef]

22) Lim KI, Nam HC, Jung KS: Effects on hamstring muscle extensibility, muscle activity, and balance of different stretching techniques. J Phys Ther Sci, 2014, 26: 209-213. [Medline] [CrossRef]

23) Lee JH, Park SJ, Na SS: The effect of proprioceptive neuromuscular facilitation therapy on pain and function. J Phys Ther Sci, 2013, 25: 713-716. [Medline] [CrossRef]

24) Busarello FO, Souza FT, Paula GF, et al.: Ganho de extensibilidade dos músculos isquiotibiais comparando o alongamento estático associado ou não à crioterapia. Fisioter Mov, 2011, 24: 247-254. [CrossRef]

25) Mallmann JS, Moesch J, Tomé F, et al.: Comparação entre o efeito imediato e agudo de três protocolos de alongamento dos músculos isquiotibiais e paravertebrais. Rev Bras Clin Med, 2011, 9: 354-359.

26) Knight CA, Rutledge CR, Cox ME, et al.: Effect of superficial heat, deep heat, and active exercise warm-up on the extensibility of the plantar flexors. Phys Ther, 2001, 81: 1206-1214. [Medline]

27) Funk D, Swank AM, Adams KJ, et al.: Efficacy of moist heat pack application over static stretching on hamstring flexibility. J Strength Cond Res, 2001, 15: 123-126. [Medline]

28) Russo AF, Adail KP, Ponte MG: A eficácia do alongamento ativo comparado ao ultrassom terapêutico no ganho de flexibilidade aguda dos músculos isquiotibiais. Fisioterapia Ser, 2011, 6: 4-8.

29) Morishita K, Karasuno H, Yokoi Y, et al.: Effects of therapeutic ultrasound on range of motion and stretch pain. J Phys Ther Sci, 2014, 26: 711-715. [Medline] [CrossRef] 